\title{
Odešla slavistka prof. dr hab. Halina Janaszek-Ivaničková
}

\author{
Libor Pavera (Praha)
}

V posledních letech jsme uvykli čítat zprávy o odchodech slavistů z výrazné badatelské generace narozené ve dvacátých a třicátých letech 20. století, která spoluutvářela obor v jeho poválečné historii. K silné generaci světově známých slavistů náležela rovněž polská profesorka Halina Janaszek-Ivaničková, o jejímž úmrtí se badatelská veřejnost dověděla v červnu 2016 (zemřela 12. 6. 2016, její ostatky byly rozptýleny 21. 6. v rodinném hrobě na Vojenském hřbitově na Powązkach).

V posledních letech života, i když již vzdálena od práce akademické sensu stricto i od práce pedagogické, jíž se činně věnovala rovněž v čase zaslouženého odpočinku, soustředila svoji pozornost (1) jednak na dějiny komparatistiky a slavistiky a na sledování proměň oboru v širokém časovém záběru několika posledních desetiletí na materiálu konferenčních příspěvků, (2) jednak na historii a osudy své vlastní rodiny. Výsledky z prvé oblasti se dočkaly publikování ( $W$ meandrech rwacej rzeki, czyli o kongresach Międzynarodowego Stowarzyszenia Literatury Porównawczej z historia w tle. In: Komparatystyka dla humanistów. Varšava, 2011, s. 321-463), výstupy z druhé oblasti zůstaly v rukopise a zřejmě nedokončeny.

Každý z běžných lidí touží po identifikaci. Ta rodinná je pro sebeuvědomění patrně nejdůležitější: Halina se o své rodině musela dovídat složitými cestami a nepř́ímo, pátrala celý život po svých předcích, příbuzných a všech, kdo by jí osvětlili temná místa z života jejího i její rodiny. Narodila se 12. 12. 1931 do rodiny důstojníka Armii Krajowej plukovníka Václava Piotra Janaszka a Natalie Domicelly z rodu Goździků. Její životní osudy vydají na kvalitní „roman à clef“: v době před druhou světovou válkou nejprve matka emigrovala do Kanady, a poté, co otec zahynul rozstř́len německými kulkami ve varšavském povstání, Halina osiřela a zakrátko ji převezli do slezských Miechovic u Bytomi do dětského domova, kde později zahájila gymnazijní studium. Otcův př́itel generál Jan Mazurkiewicz ji tam našel v roce 1947 a od té doby Halina žila spolu s Janem a Marií Mazurkiewiczovými ve Varšavě. Ale ani tato etapa jejího života nebyla jednoduchá: většina účastníků varšavského povstání byla v poválečném období kriminalizována, a týkalo se to rovněž manželi̊ Mazurkiewiczových. V roce 1951 skončila Halina Janaszek gymnázium Marie Curie-Skłodowské a zahájila slavistická studia na varšavské univerzitě; studium úspěšně zakončila o pět let později magisterskou prací na téma Románová trilogie Karla Čapka Hordubal, Povětroň, Obyčejný život (Powieściowa trylogia Karola Čapka „Hordubal”, „Meteor”, „Zwyczajne życie”) psanou pod vedením Stefana Żołkiewskiego. K Čapkovi se 
později vracívala v další badatelské dráze několikrát a dá se říci, že se českému spisovateli meziválečné doby stala vynikající interpretkou světového významu.

Ihned po studiích se prostřednictvím polského ministerstva vysokého školství ocitá na Slovensku, na bratislavské Univerzitě Komenského, v pozici lektorky polského jazyka a literatury. Následující léta byla významná nejen pro badatelčin vývoj, ale i pro bratislavskou univerzitu, neboṫ zásluhou Haliny Janaszek v Bratislavě vznikají polonistická studia - už v roce 1957 připravila čtyřletý studijní program, vypracovala skripta, slovníky, antologie a jiné studijní materiály potřebné budoucím adeptům polonistiky. Mezitím také začala publikovat v časopisech (napřs. Kultúrny život) a založila Klub milovníků polské kultury. Na Slovensku žila 18 let se svým manželem Kolomanem Ivaničkem, s nímž měla dvě děti, Małgorzatu a Kolomana. Jejím druhým manželem byl spisovatel Edward Kurowski.

V Bratislavě pracovala na doktorské práci s titulem Problem inteligenta w twórczości Stefana Żeromskiego (obhajoba proběhla ve Varšavě 1967, oponenty byli Henryk Markiewicz a Artur Hutnikiewicz). Na Filozofické fakultě Univerzity Komenského se v roce 1973 habilitovala prací Dwa modele inteligenta w polskiej prozie na przetomie XIX $i$ XX wieku, habilitace byla v Polsku nostrifikována na hodnost habilitovaného doktora (dr hab.). V roce 1983 se stala mimořádnou profesorkou (prof. nadzw.) a v roce 1992 byla jmenována profesorkou řádnou.

V roce 1974 se vrátila do Polska. Pracovala ve Varšavě v Polské akademii věd (PAN) v oddělení slovanských studií (později Instytut Słowianoznawstwa), kde vykonávala řadu vysokých řídících funkcí (mj. hlavní redaktorka Pamiętnika Słowiańskiego, předsedkyně vědecké rady apod.). $\mathrm{V}$ porevolučním období se znovu vrátila $\mathrm{k}$ vysokoškolské činnosti a začala od roku 1992 přednášet bohemistiku, slovakistiku a komparatistiku na Slezské univerzitě v Katovicích (1992-2002) a na varšavské univerzitě (1999-2001) pronesla cyklus přednášek o postmodernismu, v letech 2003-2011 vedla katedru polonistiky na Mazowiecké humanisticko-pedagogické vysoké škole v Łowiczu a jako promotorka vedla desítky prací bakalářských, magisterských i doktorských.

V Polsku své práce otiskovala v mnoha časopisech (Nowe Książki, Życie Literackie, Kultura, Pamiętnik Słowiański aj.), stejně jako v bývalém Československu (Kultúrny život, Slovenské pohlady, Slavica Slovaca, Predvoj, Slavia a Práca) nebo jinde ve světě. Již za působení na Slovensku si vychovala několik svých žáků-polonistů, k nimž patřili pozdější profesoři polonistiky na bratislavské univerzitě Jozef Hvišč a Marta Pančíková nebo Marián Servátka, první slovenský velvyslanec v Polsku (po rozdělení Československa v roce 1993). Mnoho žáků, př́mých i nepřímých, má i v ostatních zemích. Byla členem mnoha domácích, polských profesních nebo stavovských sdružení a organizací, např. členkou Komitetu Słowianoznawstwa PAN nebo Związku Literatów Polskich, ale aktivní byla rovněž v organizacích mezinárodních, např. v mezinárodní komparatistické organizaci ICLA (International Comparative Literature Association) a Fédération Internationale des Langues et Littératures Modernes, v Komisi srovnávacích literatur při Mezinárodním komitétu slavistů, kterou po několik posledních let řídila.

Velikou část svého vědeckého díla literárněvědného i překladatelského věnovala Halina Janaszek-Ivaničková textům a činnosti českého spisovatele Karla Čapka. Věnovala se 
mu v diplomové práci a poté v rozsáhlé monografii Karel Čapek, czyli Dramat humanisty (1962), později se k tématu vrátila v letech osmdesátých znovu - v knize Karel Čapek (1985). První kniha o Čapkovi vyrůstá ještě z doby, kdy se československá věda jen pozvolna vyrovnávala s tvorbou spisovatele, který spolupracoval s prvním československým prezidentem T. G. Masarykem, tvořil literaturu a dramata namířená proti nedemokratickým postupům a usiloval proměnit svět - tak jako Čapkův otec léčil, Čapek metaforicky řečeno hledal lék na problémy technicky i technologicky složitého světa a sledoval obtížný život člověka v něm. Tyto humanistické tradice Janaszek-Ivaničková ve své monografii připomíná a Čapkovu tvorbu zasazuje do kontextu filozofického proudění 20. století. Problém zodpovědnosti inteligence řešila nejen v případě Čapkově, ale i u polského autora Stefana Żeromského (Świat jako zadanie inteligencji. Studium o Stefanie Żeromskim, 1971).

Sama nebo ve spoluautorství se podílela na tvorbě učebních materiálů určených pro výuku polštiny a polské literatury na bratislavské univerzitě, např. Pol'sko-slovenský a slovensko-pol'ský vreckový slovnik (1963), Učebnica poľštiny pre samoukov. Kluč k cvičeniam. Pol'sko-slovenský - slovensko-pol'ský slovnik (1968) aj. Slovakistická témata se u ní objevují i později, když se již Janaszek-Ivaničková vrátila do Polska - v knize věnované působení a odkazu Ludovíta Štúra: Kochanek Stawy. Studium o Ludovície Štúrze (1978).

V této době se již naplno věnuje problematice literárněvědné komparatistiky, kterou zpracovala ve dvakrát vydané knize $O$ wspótczesnej komparatystyce literackiej (1980, rozšířené a doplněné vydání 1989), ale v praktické rovině i v bilaterálně orientovaných sbornících nebo knihách, např. Misjonarze i konsumenci. Literatura $i$ wartości w krajach stowiańskich (1987) nebo Wymiana literacka polsko-czeska i polsko-stowacka w czterdziestoleciu Polski Ludowej (1985).

Právě sledování soudobých světových trendů v oblasti komparatistiky učinilo z Janaszek-Ivaničkové první badatelku ze slovanských zemí, která psala o postmodernismu již v osmdesátých letech 20. století jako o novém jevu, s nímž bude nutno se vyrovnat v oblasti komparatistiky, resp. slavistiky. Hlavně to bylo v jejím vystoupení na varšavské konferenci Od modernizmu po współczesność v roce 1988 (Nowy problem w badaniach nad literatura światowa: postmodernizm, Pamiętnik Słowiański, 1988). Postmodernistická tematika ve srovnávacím kontextu se pak u ní objevuje velice často ve studiích, sbornících i v knihách vydávaných v devadesátých letech 20. století a na počátku 21. století.

Zatímco v knize Od modernizmu do postmodernizmu (1996) ještě probírala problematiku modernismu a jevů, které připravovaly nástup širokého filozofického a uměleckého proudu - postmodernismu, kniha navazující na tuto linii Nowa twarz postmodernizmu (2002) je již plně soustředěna na postmodernismus a na jevy, které jej doprovázejí. K uvedeným knihám se patří připojit, že autorka si všímala nejen filozofického zázemí proměn modernismu v postmodernistické pojetí světa a změn v autorských poetikách, ale sledovala rovněž proměnu myšlení o literatuře a umění z pohledu komparatistického, jak o tom dobře vypovídá její Antologia zagranicznej komparatystyki literackiej (1997).

V roce 1998 sledujeme Halinu Janaszek Ivaničkovou v Japonsku: vyhrála konkurs japonského Ministerstva pro vědu a měla možnost studovat světové, v tom i japonské, práce o postmodernismu v Slavic Research Center na Hokkaido University v Sapporo (na půlročním pobytu získala pozici fellow visiting professor). 
Pozornost u ní vzbudily hlavně proměny, k nimž došlo v souvislosti s vpádem postmodernismu do slovanského literárního prostředí (rozrušení tradičního příběhu a rozpad tzv. velkých přiběhů, odmítnutí totalitarismu a s tím související zpolitizování literatury i kultury, odklon od patriarchální kultury k feminismu, nápadněǰši sledování menšin a kultury ,jiných“, změny v oblasti žánrů a stylů aj.). Právě komparativní zřetele a znalost zahraniční sekundární literatury spolu se zájmem o filozofické pozadí problematiky náleží mezi signifikanty, odlišující Janaszek-Ivaničkovou od ostatních literárněvědných badatelů, sledujících projekce postmodernismu prostřednictvím mimoliterárních skutečností nebo prostřednictvím proměn techniky psaní a transformací tvưrčích konvencí a stylů.

Spolupracovala s mnoha badateli ve světě, např. s Douwe Fokkemou, Tiborem Žilkou, Ivem Pospíšilem (na opavské konferenci Postmodernismus v české a slovenské próze o projekci postmodernismu ve dvou západoevropských literaturách (české a slovenské) pronesla hlavní referát spolu s I. Pospíśilem a T. Žilkou). Ačkoliv rytmus nástupu postmodernismu do slovanského prostředí byl pomalejší nežli na Západě, $v$ jeho struktuře a rysech v obou teritoriích nespatřuje badatelka př́lišné odlišnosti, dokonce na nejednom místě její knihy probleskuje myšlenka (protichůdná např. D. Fokkemovi), že v totalitním prostředí komunistických režimů se vytvořily daleko příhodnější podmínky pro konstituování postmodernismu než ve světě západním, v němž je postmodernismus namnoze spojován s rozvinutou infrastrukturou, masmédii a masovou kulturou vůbec. $\mathrm{V}$ obou teritoriích (euro-americkém i postkomunistickém) lze v posledním půlstoletí období spatřovat obdobné společenské procesy (prosazování autoritativních a totalitaristických pravicových nebo levicových modelů, oslavujících rozum, neviditelnou ruku trhu a tzv. kolektivní zkušenost, kterou ve východní sfére reprezentovala strana), proti nimž postmodernismus postavil mnohost pohledů na skutečnost, toleranci, pluralismus a tzv. malé narace. Situaci však nelze vyložit zcela takto jednoznačně a mechanicky, je třeba stále stav konfrontovat a hledáním se dobírat preciznějších odpovědí vzhledem k národním literaturám a určitým areálům.

Jejím osobitým vkladem polské i slovanské literární vědě v oblasti výzkumu postmodernismu byly rovněž konference, které uspořádala a z nichž vydala podnes cenné sborníky. Po dlouhou dobu platily za východisko bádání o postmodernismu a svého druhu vzor. Sem se patří uvést např. kolektivní knihu Postmodernism in Literature and Culture of Central and Eastern Europe (konference 1993, sborník vyšel 1996 za redakce Haliny Janaszek-Ivaničkové a Douwe Fokkemy ve dvou mutacích, anglické a polské). Přispěla svými cennými úvahami o podobě středoevropské podoby postmodernismu do mnoha sborníků z konferencí i do samostatných publikací, např. do světově proslulé publikace International Postmodernism. Theory and Literary Practice, která vyšla za redakce Hanse Bertense a Douwe Fokkemy (Amsterdam - Philadelpia, 1997).

V prvních letech z počátku 21. století se Halina Janaszek-Ivaničková podílela na tvorbě mezinárodní sítě badatelů v rámci projektu nazvaného Literatury stowiańskie po roku 1989 w dialogu z Europa $i$ światem. Nowe zjawiska, tendencje, perspektywy (z projektu vyšly v roce 2005 celkem 4 svazky publikací: t. I Transformacja, t. II Feminizm, t. III Podmiotowość a t. IV Mniejszości). Na univerzitě v Lowiczi uspořádala pak mezinárodní konferenci, kterou finančně i morálně podpořila japonská slavistika z Hokkaido University v Sapporo, s níž po léta naše jubilantka spolupracuje, jejím výsledkem byla anglická publikace The 
Horizons of Contemporary Slavic Comparative Literature Studie (2007, s výjimkou ruských badatelů všichni přispěli do knihy v anglickém jazyce).

Za své knihy, organizátorskou činnost i jiné práce v oblasti literární vědy a kultury byla v průběhu života několikrát zaslouženě oceněna, např. Zlatým křížem za zásluhy (Polsko), Cenami rektora Slezské univerzity v Katovicích, Medailí L'udovíta Štúra (Slovensko), Medailí Karla Hynka Máchy (Československo), Zlatou medailí Karla Čapka (Česká republika), Medailí za zásluhy o Filozofickou fakultu UK v Bratislavě (Slovensko), v roce 2002 ji polský prezident Aleksandr Kwaśniewski ocenil Krzyżem Oficerskim Orderu Odrodzenia Polski, rektorem a senátem Wyższej Szkoły Humanistyczno-Pedagogicznej w Łowiczu byla oceněna medailí „Amico Mazoviae Mater“.

U přiležitosti jubilea Haliny Janaszek-Ivaničkové dal její tehdejší nadřízený Emil Tokarz, vedoucí slavistiky na Slezské univerzitě v Katovicích, podnět k vytvoření sborníku („festschriftu“), do něhož přispěli badatelčini žáci a přátelé z celého světa. Vznikl svazek Nadzieje $i$ zagrożenia. Slawistyka $i$ komparatystyka u progu nowego tysiaclecia. Studia ofiarowane Profesor Halinie Janaszek-Ivaničkovej (2002). Jak napovídá sám titul - Nadzieje i zagrożenia - slavistika a komparatistika stojí nejen před četnými nadějemi (např. elektronizace knihy a její přiblížení širšímu publiku), ale prognózy zároveň straší mnoha chmurami (např. terorismem, ekonomicky bipolárním světem extrémně chudých a bohatých apod.). I na tyto jevy bude muset literární věda 21. století umět včas reagovat.

Až do posledních chvil života měla zájem o vědění ze všech oblastí lidského života. Své rozhleděnosti po světě využívala při formulování názorů obecných, i týkajících se jedince, nejen pro chvíli „tady a ted“", ale i pro možnou budoucnost. Nikdy se nenechala omezovat ideologiemi ani svazovat metodologiemi, přesahovala obojí, šla svou cestou. Byla lidsky dobrým a přejícím člověkem naplněným vírou v lepší přriští. Slavistka Halina Janaszek-Ivaničková odešla pětaosmdesátiletá nad rozdělanou prací: zůstavila nám veliké dílo literárněvědné, překladatelské a esejistické, týkající se komparatistiky a slovanských literatur 19., 20. i 21. století.

prof. PhDr. Libor Pavera, CSc.

Praha, Česká republika

I.pavera@seznam.cz 
